\title{
Prevencija poremećaja prehrane Prevention of eating disorders
}

\author{
Marija Ćuk', Josipa Rožman² \\ 1 Dom zdravlja Jastrebarsko, Ulica kralja Tomislava 29, 10450 Jastrebarsko \\ 2 Opća bolnica Karlovac, Odjel za psihijatriju, Andrije Štampara 3, 47000 Karlovac
}

\section{Sažetak}

Uzroci poremećaja prehrane povezuju se s biološkim, psihološkim i sociokulturalnim čimbenicima, a dovode do promjena obrazaca ponašanja koji izmiču kontroli te se javlja nezadovoljstvo vlastitim izgledom i sobom u cjelini. Poremećaji prehrane javljaju se postepeno - osoba ulazi u začarani krug prejedanja, gladovanja, povraćanja, zlouporabe tableta. Najveća je teškoća u poremećajima prehrane u neprepoznavanju navedenih problema (ili negiranje postojanja problema) što vodi narušenom fizičkom i mentalnom stanju s lošim ishodom bolesti. Cilj je rada prikazati glavne poremećaje prehrane, etiologiju nastanka poremećaja te mogućnosti liječenja i prevencije iz pozicije sestrinske skrbi. U radu su prikazani specifični poremećaji prehrane: anoreksija, bulimija i prejedanje, kao i najčešći nespecifični poremećaji hranjenja: pregoreksija, ortoreksija, diabulimija i drunkoreksija. Uloga medicinske sestre važna je u: edukaciji i prevenciji poremećaja prehrane; osvješćivanju prisutnog problema; edukaciji o mogućim čimbenicima koji se povezuju s nastankom poremećaja prehrane i štetnim navikama; pružanju psihološke podrške te pomoći prilikom rješavanja strahova i problema; procjeni i praćenju zdravstvenog stanja bolesnika. Navedeni poremećaji prehrane najčešće se javljaju kod adolescenata te mlađih žena iako je moguća pojava i u srednjoj životnoj dobi. Učestaliji su kod žena nego muškaraca. Posljedice poremećaja prehrane ostavljaju negativan efekt na zdravlje. Potrebna je suradnja sa zdravstvenim stručnjacima te edukacija obitelji, prijatelja i šire zajednice. Također, poremećaji prehrane zahtijevaju dugotrajno liječenje. Različiti su razlozi nastanka poremećaja hranjenja te je, sukladno tome, potrebno svakom pacijentu pristupiti individualno i holistički. Poremećaji hranjenja različito se manifestiraju, no bez obzira na različitost, zahtijevaju liječenje te stručnu pomoć.

Ključne riječi: poremećaji hranjenja, bulimija, anoreksija, prevencija, liječenje Kratak naslov: Poremećaji prehrane

\begin{abstract}
The causes of eating disorders are associated with biological, psychological and sociocultural factors which lead to changes in patterns of behavior that can get out of control. In people with eating disorders usually occurs dissatisfaction with their appearance and personal dissatisfaction in general. Eating disorders appear gradually, the person enters a vicious circle of overeating, starvation, vomiting and abuse of pills. The biggest problem in eating disorders is in not recognizing the above difficulties or denying the existence of the problem which leads to impaired physical and mental condition with a poor disease outcome. The aim of this paper is to present the main eating disorders, etiology of disorder, treatment and prevention options from a nursing perspective. The paper presents specific eating disorders - anorexia, bulimia and overeating, as well as the most common nonspecific eating disorders: pregorexia, orthorexia, diabulimia and drunkorexia. The role of the nurse is important in educating and preventing eating disorders, raising awareness of the problem, educating about possible risk factors associated with eating disorders and harmful habits, providing psychological support and assistance in resolving fears and problems, assessing and monitoring the health of patients. These eating disorders most often occur in adolescents, younger women although its occurrence is also possible in middle age. They are more common in women than men. The consequences of eating disorders negatively affect the health of patients. Cooperation with health professionals is needed, as well as education of family, friends and the wider community. Eating disorders require long-term treatment. There are various reasons for the occurrence of eating disorders, and accordingly, it is necessary to approach each patient individually and holistically. Eating disorders manifest themselves differently, but regardless of the differences, they require treatment and professional help.
\end{abstract}

Keywords: eating disorders, bulimia, anorexia, prevention, treatment Running head: Eating disorders

Received November $30^{\text {th }} 2020$;

Accepted December $11^{\text {th }} 2020$;

Autor za korespondenciju/Corresponding author: Rožman Josipa, Odjel za psihijatriju, Opća bolnica Karlovac, Andrije Štampara 3, e-mail:petrunic.josipa@gmail.com, Tel:0958019871

\section{Uvod}

Poremećaji hranjenja spadaju u najčešće psihičke poremećaje i povezani su s brojnim tjelesnim komplikacijama koje nose rizik ranije smrti. Hranjenje je proces koji uključuje doživljaje vanjskog i unutarnjeg svijeta te je vezan za emocije i iskustva još od najranijeg razvoja. Bulimia nervosa i anorexia nervosa dva su glavna oblika poremećaja hranjenja [1]. Cilj je rada prikazati glavne poremećaje prehrane, etiologiju nastanka poremećaja te mogućnosti liječenja i prevencije iz pozicije sestrinske skrbi.

\section{Introduction}

Eating disorders are among the most common mental disorders and are associated with a number of physical complications that carry the risk of early death. Nutrition is a process that involves experiences of both the outer and inner world and is related to emotions and experiences from the earliest development. Bulimia nervosa and anorexia nervosa are the two main forms of eating disorders [1]. The aim of this paper is to present the main eating disorders, the etiology of the disorder and the possibilities of treatment and prevention from the position of nursing. 
Poremećaji prehrane gotovo uvijek započinju kao dijetalna prehrana, ali ne tiču se samo hrane i težine. Osobe koje pate od njih također pate i od nedostatka samopouzdanja, depresije, anksioznosti ili nekih drugih psiholoških stanja [1]. Učestalost poremećaja hranjenja raste u razvijenim zemljama i posljedično se povezuje s brojnim komplikacijama i smrtnim ishodom. Ekstremna zabrinutost zbog tjelesnog oblika i tjelesne težine zajednička je anoreksiji i bulimiji, kao i različita ponašanja osobe usmjerena na kontroliranje tjelesne težine [2]. Osobe s poremećajima hranjenja često se važu te su zato zabrinute za svako, pa i najmanje variranje u težini, a druge pak potpuno izbjegavaju vaganje i stalno su u strahu zbog težine. Može biti prisutna i zaokupljenost oblikom tijela, što objašnjava stalno provjeravanje oblika tijela (promatranje dijelova tijela u ogledalu, dodirivanje nakupina sala rukama, uspoređivanje vlastita tijela s tijelima drugih osoba). Nekada se pridavanje prevelike važnosti težini i obliku tijela manifestira pravim prezirom prema vlastitome tijelu, što se izražava izbjegavanjem gledanja vlastita tijela ili izlaganja dijelova tijela pogledu drugih [3]. Najveći problem u poremećajima prehrane je u neprepoznavanju navedenih znakova (ili negiranju postojanja problema) što vodi narušenom fizičkom i mentalnom stanju s lošim ishodom bolesti.

\section{Poremećaji hranjenja}

Svi su poremećaji prehrane dijelom psihijatrijske prirode. Pogled na vlastito tijelo izaziva neugodne osjećaje koje pojedinac nastoji ublažiti određenim pothvatima u prehrani ili promjenom tjelesne težine. Tjelesna težina izražava se indeksom tjelesne mase, a kod poremećaja prehrane javlja se gubitak tjelesne mase. BMI - Indeks tjelesne mase, jedan je od načina procjene uhranjenosti. Relativno ga je jednostavno izračunati ili očitati iz tablica [4]. Vrijednosti preporučenog BMl-a iste su za oba spola, iznosi 18,5 - 24,9 kg/ $\mathrm{m} 2$ prema klasifikaciji Svjetske zdravstvene organizacije za europsko stanovništvo [5]. Ove se norme mogu primjenjivati za muškarce i žene iznad 16 godina, dok je za djecu i adolescente neophodno upotrebljavati tablice distribucije indeksa tjelesne mase s obzirom na dob i spol [6].

\section{Anoreksija}

Anorexia nervosa (anoreksija) ozbiljan je poremećaj hranjenja koji je karakteriziran namjernim izbacivanjem unosa hrane. Bolest je prvi opisao Richard Morton još 1689. godine kao samovoljno izgladnjivanje žene koja je ravnodušno odbijala liječenje [7]. Poremećaj počinje kod adolescenata kao želja za savršenim tjelesnim izgledom ili kao reakcija na neuspjeh, primjerice, nakon odbijanja u ljubavi, prekida ljubavne veze, ismijavanja u društvu ili nakon primjedbe bliske osobe da bi bilo dobro da smršavi. Osoba tada započinje s dijetom i slijedi strože režime prehrane od svojih vršnjaka. Kad su ostali već prekinuli dijetu, anoreksična osoba, poticana tjeskobom, nastavlja dalje. Ljudi takvoj osobi govore da je mršava i ona uživa u tome, no intimno i dalje smatra da bi trebala izgubiti još kilograma [4]. Naziv anorexia označava težak gubitak apetita, a naziv nervosa ukazuje na to da su razlozi emocionalne naravi. Anoreksija zapravo nije u potpunosti precizan naziv jer mnoge anorek-
Eating disorders almost always start as a diet, but it's not just about food and weight. People who suffer from them also suffer from lack of self-confidence, depression, anxiety or some other psychological state [1]. The incidence of eating disorders is increasing in developed countries and is consequently associated with a number of complications and deaths. Extreme concerns about body shape and weight are common to anorexia and bulimia as well as various behaviors aimed at weight control [2]. People with eating disorders often weigh themselves and are therefore concerned about the slightest variation in weight; others completely avoid weighing and are constantly in fear of their weight. Preoccupation with body shape may also be present, which explains constantly checking of their body shape (observing body parts in a mirror, touching fat accumulations with your hands, comparing your own body with other people's bodies). Sometimes attaching too much importance to body weight and shape is manifested by true contempt for one's own body, which is expressed by avoiding looking at one's own body or exposing body parts to others [3]. The biggest problem in eating disorders is in not recognizing the above (or denying the existence of the problem) which leads to impaired physical and mental condition with a poor outcome of the disease.

\section{Eating disorders}

All eating disorders are part of a psychiatric nature. The sight of one's own body causes unpleasant feelings that an individual tries to alleviate by certain interventions in the diet or by changing body weight. Body weight is expressed by body mass index, and weight loss occurs in eating disorders. BMI - Body Mass Index is one way to assess nutrition status. Of all the known indices, the body mass index is most closely related to the amount of excess adipose tissue in the human body, and in addition it is relatively easy to calculate or read from the tables [4]. The values of the recommended BMI are the same for both genders, it is from 18.5 to $24.9 \mathrm{~kg} / \mathrm{m} 2$ according to the classification of the World Health Organization for the European population [5]. These norms can be applied for men and women over 16 years of age, while for children and adolescents it is necessary to use tables of body mass index distribution according to age and gender [6].

\section{Anorexia}

Anorexia nervosa is a serious eating disorder, characterized by deliberate expulsion of food intake. The disease was first described by Richard Morton in 1689 as the arbitrary starvation of a woman who indifferently refused treatment. The disorder begins in adolescents as a desire for a perfect physical appearance or as a reaction to failure, for example after being rejected in a romantic relationship, a breakup, a ridicule in the presence of others, or a remark from a close person that it would be good to lose weight. The person then starts a diet and follows stricter diets than their peers. When the others have already stopped dieting, the anorexic person, driven by anxiety, continues on. People tell the person that he/she is thin and he/she enjoys it, but deep down he/she still thinks he/she should lose more 
sične osobe isprava ne trpe toliko od gubitka apetita koliko se boje debljanja [7]. Nastupanje bolesti gotovo je neprimjetno. Osoba koja je do tada bila društvena, odjednom se počinje povlačiti iz društva i postaje zaokupljena dijetama za mršavljenje. Sve se više zanima za kalorijsku vrijednost hrane te izbjegava sve što po njezinu mišljenju deblja. Jelovnik se postupno svodi na sve manji broj namirnica koje su pripremljene bez dodataka koje sadrže kalorije, a glad ublažava tako što pije velike količine vode [4]. Te osobe odbijaju jesti dovoljno da bi zadržale minimalnu tjelesnu težinu, a intenzivno se boje da će postati gojazne [8]. Samoizgladnjivanje koje anoreksične osobe same sebi nameću, uzrokuje promjene koje su katkad gotovo ireverzibilne. Procjene se razlikuju, no oko $5 \%$ takvih osoba umire. Kod drugih $25 \%$ tijek bolesti nastavlja se bez poboljšanja i tijekom dvije godine nakon postavljanja dijagnoze, a preostale osobe koje pate od anoreksije tijekom terapije se postupno počinju vraćati na normalnu tjelesnu težinu [7].

Glavna su obilježja anoreksije nervoze:

- namjeran gubitak tjelesne težine;

- mršavljenje;

- odbijanje ili smanjenje unosa hrane;

- strah od dobivanja na težini;

- poremećaj slike tijela;

- amenoreja (izostanak menstruacije) kod žena.

Anoreksija je jedan od čestih poremećaja hranjenja, a osobito je značajan porast oboljelih u posljednjih nekoliko desetljeća. Pojavljuje se kod 0,5 \% - $1 \%$ adolescentnih djevojaka. Bolest se općenito mnogo češće javlja kod žena. Može se javiti i prije puberteta, u srednjoj dobi pa čak i u menopauzi. Kod muškaraca se javlja obično u razdoblju adolescencije [9].

\section{Liječenje anoreksije}

Psihoterapija, redovno medicinsko praćenje i vođenje pravilne prehrane trebali bi biti dio svakog programa liječenja anoreksije. Liječenje anoreksije razlikovat će se ovisno o stadiju u kojemu se prepozna te o pacijentovoj spremnosti na suradnju. Hospitalizacija je nužna kod osoba koje su izgubile više od $25 \%$ tjelesne težine. Provodi se individualna psihoterapija kako bi se otkrili emocionalni problemi i teškoće u međuljudskim odnosima koji su potencijalno uzroci bolesti. Obiteljska terapija također je vrlo važna ako pacijent živi s obitelji, a bihevioristička terapija može pomoći u mijenjanju štetnih navika [4]. Terapija anoreksije proces je koji se odvija u dva dijela. Izravni je cilj terapije da se anoreksičnoj osobi pomogne vratiti tjelesna težina kako bi se izbjegle medicinske komplikacije i smrt [7]. U cijelosti, prognoza obično nije dobra ni kod bolesnika koji postignu odgovarajuću tjelesnu masu. Ostaje preokupacija hranom i tjelesnom težinom, socijalni kontakti vrlo su siromašni i mnogi pacijenti postaju depresivni [8]. U liječenju osoba s anoreksijom nervozom najveći problem predstavlja činjenica da sama osoba ne uviđa ozbiljnost nastalog problema te pruža otpor prilikom pokušaja pomoći [10]. Psihoterapija se primjenjuje nakon što osoba izađe iz stanja životne opasnosti i ona je stvar izbora (iako se obavezno preporučuje) weight [4]. The name anorexia means severe loss of appetite, and the name nervosa indicates that the reasons for this are emotional in nature. Anorexia is not really a very precise name, because many anorexic people do not suffer so much from loss of appetite, as they are afraid of gaining weight [7]. The onset of the disease is almost imperceptible. A person who was social until then suddenly begins to withdraw from the company of others and becomes preoccupied with weight loss diets. He/she is increasingly interested in the caloric value of food, and avoids anything that he/she thinks is making him/her gain weight. The menu is gradually reduced to a decreasing number of foods, which are prepared without additives that contain calories, and hunger is alleviated by drinking large amounts of water [4]. These individuals refuse to eat enough to maintain a minimum body weight, and are intensely afraid that they will become obese [8]. The self-starvation that anorexic people impose on themselves causes changes that are sometimes almost irreversible, estimates vary, but about $5 \%$ of such people die. In the other $25 \%$, the course of the disease continues without improvement for two years after diagnosis, and the rest gradually begin to return to normal weight during therapy [7].

The main features of anorexia nervosa are:

- Intentional weight loss,

- Weight loss,

- Refusal of food or reduced food intake,

- Fear of gaining weight,

- Body image disorder and amenorrhea in women.

Anorexia is one of the common eating disorders, and there has been a particularly significant increase in diseased patients in the last few decades. It occurs in 0.5 to $1 \%$ of adolescent girls. The disease occurs much more often in women. It can occur before puberty, in middle age and even in menopause. In men, it usually occurs during adolescence [9].

\section{Treatment of anorexia}

Psychotherapy, regular medical monitoring, and proper nutrition should be part of any anorexia treatment program. The treatment of anorexia will vary depending on the stage at which the patient's willingness to cooperate is recognized. Hospitalization is necessary in people who have lost more than $25 \%$ of their body weight. Individual psychotherapy is performed, in order to discover emotional problems and difficulties of interpersonal relationships that may be behind the illness. Family therapy is also very important if the patient lives with a family, and behavioral therapy can help change harmful habits [4]. The therapy of anorexia is a process that takes place in two segments. The direct goal of therapy is to help the anorexic person regain weight, to avoid medical complications and death [7]. Overall, the prognosis is not good in patients who achieve adequate body weight. Preoccupation with food and body weight remains, social contacts are very poor and many become depressed [8]. In the treatment of people with anorexia nervosa, the biggest problem is the fact that the person does not see the seriousness of the problem 
[10]. Psihofarmaci se nisu pokazali posebno uspješnima, no u kombinaciji s psihoterapijom pacijentu se daju antidepresivi i olanzapin koji se pokazao uspješnim za povećanje tjelesne težine. Najveći se broj osoba oboljelih od anoreksije nervoze uspješno oporavi, a kod manjeg broja osoba razvija se kronični poremećaj. Nakon prestanka simptoma anoreksije, kod nekih je pacijenata još neko vrijeme prisutno slabo zdravstveno stanje, nisko samopouzdanje i depresivnost [10].

\section{Bulimija}

Razlika između anoreksije nervoze i bulimije nervoze ni na koji način nije jasna ako se koristimo samo tjelesnom težinom kao prepoznatljivim obilježjem [11]. Poremećaj se često opisuje i kao sindrom prežderavanja/pražnjenja, a sastoji se od epizoda velikog prežderavanja nakon kojega slijedi samoizazvano povraćanje ili zlouporaba laksativa da bi se iz tijela izbacile goleme količine progutane hrane [7]. Za razliku od anoreksične osobe, osoba s bulimijom nije uvijek mršava, no obje skupine bolesnika prekomjerno brinu o vlastitoj tjelesnoj težini te imaju strah od debljanja i gojaznosti [7].

Razlikujemo dva tipa bulimije :

- purgativni tip: osoba uobičajeno pribjegava samoizazvanim povraćanjima ili zlouporabi laksativa, diuretika ili sredstava za klistiranje;

- nepurgativni tip: osobu karakterizira drugačije neodgovarajuće ponašanje, kao što je post ili pretjerano tjelesno vježbanje, ali ne pribjegava samoizazvanom povraćanju ili zlouporabi laksativa, diuretika ili sredstava za klistiranje [12].

Bolesnici s poremećajem bulimije nervoze brinu se o svojem tjelesnom izgledu, važno im je kako ih drugi vide i jesu li seksualno atraktivni. Mnogi s tom bolesti seksualno su aktivni za razliku od osoba s poremećajem anoreksije nervoze. Ne zna se mnogo o tijeku bolesti, ali je očigledno da ima bolju prognozu od anoreksije. Uobičajeni je tijek bolesti kronični i traje mnogo godina s povremenim remisijama [8].

\section{Liječenje bulimije}

Liječenje bulimije temelji se na psihoterapijskim tehnikama i farmakoterapiji ili na primjeni obiju zajedno [8]. Od psihoterapijskih je tehnika na prvom mjestu kognitivna psihoterapija, a od medikamenata antidepresivi. Najbolji rezultat pokazuje kombinacija psihoterapijske tehnike i farmakoterapije. Ako se ne liječi, bulimija uglavnom neće spontano nestati [7]. Psihološki tretmani bulimije mogu uključivati individualnu, obiteljsku ili grupnu psihoterapiju. Sesije su obično usmjerene na analiziranje ponašanja i smišljanje načina za njegovu promjenu, a pacijent slijedi određene upute između sesija [7]. Kognitivna terapija usredotočena je na istraživanje i suzbijanje negativnih misli koje su u osnovi destruktivnih navika.

\section{Prejedanje}

Prejedanje je poremećaj prekomjernog unosa hrane. Ovo stanje ne prati izazivanje povraćanja, čišćenje ili smanjen and resists any attempt to receive help from other people [10]. Psychotherapy is applied after a person is no longer in a life-threatening situation and it is a matter of choice (although it is highly recommended) [10]. Psychopharmaceuticals have not been shown to be extremely successful, but in combination with psychotherapy, antidepressants and olanzapine are given, which have been shown to be successful in weight gain [10]. Most people with anorexia nervosa successfully recover, and a small number of people develop a chronic disorder. Some people, even after no longer having symptoms of anorexia, show poor health, low selfesteem and depression for some time [10].

\section{Bulimia}

The difference between anorexia nervosa and bulimia nervosa is by no means clear if we use body weight as a recognizable feature [11]. The disorder is also often described as overeating / emptying syndrome, and consists of episodes of large overeating followed by self-induced vomiting or laxative abuse, to expel huge amounts of ingested food from the body [7]. Unlike an anorexic person, a person with bulimia is not always thin, but both groups of patients worry excessively about their own body weight and have a fear of weight gain and obesity [7].

We distinguish two types of bulimia :

- Purging type: the person usually resorts to self-induced vomiting or abuse of laxatives, diuretics or enemas,

- Non-purging type: the person has some other inappropriate behavior, such as fasting or excessive physical exercise, but does not resort to self-induced vomiting or abuse of laxatives, diuretics, or enemas [12].

Patients with bulimia nervosa care about their physical appearance, it is important to them how others see them and whether they are sexually attractive. Many with this disease are sexually active, unlike people with anorexia nervosa disorder. Not much is known about the course of the disease, but it is obvious that it has a better prognosis than anorexia. The normal course of the disease is chronic and lasts for many years with occasional remissions [8].

\section{Treatment of bulimia}

Treatment of this disease is based on psychotherapeutic techniques and pharmacotherapy or on the application of both together [8]. Of the psychotherapeutic techniques, cognitive psychotherapy is in the first place, and of the drugs, antidepressants. The best result is shown by a combination of psychotherapeutic technique and pharmacotherapy. When left untreated, bulimia will generally not go away spontaneously [7]. Psychological treatments for bulimia may include individual, family, or group psychotherapy. Sessions are usually devoted to analyzing behavior and devising ways to change it, and the patient follows certain instructions between sessions [7]. Cognitive therapy focuses on exploring and suppressing negative thoughts that underlie destructive habits.

\section{Overeating}

Overeating is a disorder of excessive food intake. This condition is not accompanied by vomiting, cleansing or redu- 
unos hrane. Bolest se sve češće pojavljuje u posljednjem desetljeću s podjednakom ili većom učestalošću nego anoreksija [9]. Poremećaj prejedanja češće se pojavljuje kod žena. Psihološka objašnjenja upućuju na nisko samopoštovanje, neprihvaćanje slike vlastita tijela i nezadovoljstvo izgledom osoba s ovim poremećajem. Pojavljuje se s drugim poremećajima hranjenja (naročito bulimijom) i depresijom [9]. Osoba ima više epizoda u kojima obilno jede. Tijekom i između epizoda nema povraćanja, čišćenja organizma laksativima i purgativima ni odbijanja hrane. Ovo stanje treba razlikovati od drugih poremećaja hranjenja, poremećaja raspoloženja, poremećaja ličnosti i shizofrenije [9].

Sve poremećaje hranjenja objedinjuje negativno percipiranje sebe s obzirom na vanjski izgled i težinu te neredovit ili povećan unos hrane. lako su najpoznatiji poremećaji prehrane anoreksija i bulimija nervoza, sve se veća pažnja pridaje i proučavanju kompulzivnog prejedanja kao posebnog poremećaja prehrane, ali i kao obrasca ponašanja što znači da ne mora nužno imati obilježja poremećaja. Kompulzivnom prejedanju treba pristupiti ozbiljno jer u odsutnosti pravovremenog liječenja može napredovati u ozbiljan poremećaj hranjenja, dok prejedanje kao obrazac hranjenja nakon nekog vremena može i prestati [13].

\section{Nespecifični poremećaji hranjenja}

Pregoreksija je izraz koji se upotrebljava za opis prisutnosti simptoma sličnih anoreksiji kod trudnica. Žene s ovim poremećajem imaju pretjeran strah od debljanja koji je povezan s trudnoćom. Koriste se raznim metodama, uključujući ekstremne rutine vježbanja i ograničenje kalorija, kako bi izbjegle povećanje tjelesne težine koje označava tijek normalne, zdrave trudnoće. Potencijalne posljedice ovakva ponašanja uključuju komplikacije u trudnoći, prijevremeni porod i razna zdravstvena stanja povezana s neobično niskom djetetovom težinom.

Ortoreksija je poremećaj prehrane koji uključuje nezdravu opsjednutost zdravom prehranom. Za razliku od ostalih poremećaja prehrane, ortoreksija je usmjerena na kvalitetu hrane, a ne količinu. Suprotno osobama koje pate od anoreksije ili bulimije, osobe s ortoreksijom rijetko su usredotočene na mršavljenje. Umjesto toga, imaju krajnju fiksaciju na „čistoću“ hrane te su opsjednuti prednostima zdrave prehrane. Ključna je manifestacija patološka opsjednutost ispravnom ishranom, a karakteriziraju je i restriktivne dijete te strogo izbjegavanje hrane za koju bolesnik vjeruje da je nezdrava ili nečista.

Diabulimija je pojam nastao u medijima koji se odnosi na poremećaj prehrane kod osoba s dijabetesom, tipično dijabetesom tipa I, pri čemu osoba namjerno ograničava unos inzulina kako bi smršavjela.

Drunkoreksija je proces koji uključuje opasnu kombinaciju gladi, prekomjernog pijenja i čestog prejedanja nakon noćnog provoda. ced food intake. The disease has become more common in the last decade, with an equal or higher frequency than anorexia [9]. Overeating will be more common in women. Psychological explanations suggest low self-esteem, unacceptance of one's own body image and dissatisfaction with the appearance of people with this disorder. It occurs with other eating disorders (especially bulimia and depression) [9]. A person has multiple episodes in which he/she eats profusely. At the same time, and between episodes, there is no vomiting, cleansing the body with laxatives and purgatives, or refusing food. This condition should be distinguished from other eating disorders, mood disorders, personality disorders and schizophrenia [9].

All eating disorders are united by a negative perception of oneself in terms of appearance and weight, and irregular or increased food intake. Although the most well-known eating disorders are anorexia and bulimia nervosa, more and more attention is paid to the study of compulsive overeating as a special eating disorder, but also as a pattern of behavior which means that it does not have to have the characteristics of the disorder. Compulsive overeating should be taken seriously because in the absence of timely treatment, it can progress to a serious eating disorder, while overeating as a pattern of eating may stop after a while [13].

\section{Non-specific eating disorders}

Pregorexia is a term used to describe the presence of symptoms similar to anorexia in pregnant women. Women with the disorder have an excessive fear of pregnancy-related weight gain and use a variety of methods, including extreme exercise routines and calorie restriction, to avoid the weight gain that marks the course of a normal, healthy pregnancy. Potential consequences of this behavior include complications in pregnancy, premature birth, and various medical conditions associated with the abnormally low weight of the child.

Orthorexia also known as orthorexia nervosa is an eating disorder that involves an unhealthy obsession with a healthy diet. Unlike other eating disorders, orthorexia mainly revolves around the quality of the food, not the quantity. Unlike anorexia or bulimia, people with orthorexia rarely focus on weight loss. Instead, they have an ultimate fixation with the "purity" of food, as well as an obsession with the benefits of a healthy diet. The key manifestation is a pathological obsession with proper nutrition, and it is also characterized by restrictive dieting, strict avoidance of food that the patient believes to be unhealthy or unclean.

Diabulimia is a term that originated in the media to refer to an eating disorder in a person with diabetes, typically type I diabetes, in which a person intentionally restricts insulin in order to lose weight.

Drunkorexia - The process involves a dangerous combination of hunger, excessive drinking and frequent overeating after a night out. 


\section{Uloga medicinske sestre u prevenciji poremećaja prehrane}

Planiranje programa prevencije i probira bolesti složen je proces na koji utječu stavovi brojnih sudionika - kako stručnjaka, tako i opće populacije. Odnos društva prema prevenciji bolesti mijenja se u skladu sa svjetonazorom, društveno-političkim uređenjem i socijalno-ekonomskim mogućnostima [14].

Prevenciju bi trebalo provoditi od predškolske dobi. Medicinska sestra treba sudjelovati u izradi jelovnika za dječje vrtiće, škole, bolnice i druge ustanove u kojima borave djeca, adolescenti i odrasle osobe. Cilj zdravstveno-odgojnih aktivnosti, uz izlaganje djece zdravim namirnicama, jest upoznati djecu s osnovnim pojmovima vezanima za prehranu, osnovnim nutrijentima potrebnima za normalno funkcioniranje organizma, preporučenim dnevnim količinama hrane, ali i s osnovnim poremećajima prehrane [11].

Prevencija poremećaja hranjenja može se provoditi u školama organiziranjem radionica za učenike viših razreda osnovnih škola te učenike srednjih škola s ciljem umanjivanja stereotipa o ljepoti, oblikovanju tijela, samopouzdanju te s ciljem razvijanja pravilnih prehrambenih navika kako bi se postiglo pozitivno prihvaćanje vlastita tijela [11]. Programi prevencije i probira mogu se primijeniti na cjelokupnu populaciju s povećanim rizicima za razvoj bolesti ili pak individualno na pojedino dijete s čimbenicima rizika ili bez njih [14].

Oboljele i njihove obitelji treba uputiti u udruge i grupe samopomoći u kojima mogu dobiti potrebnu pomoć i podršku. Razmjenjujući informacije s drugim članovima, osvijestit će da nisu sami u tome. Ako osjete da bolest izmiče kontroli, tamo također mogu dobiti informacije o zdravstvenim ustanovama u kojima mogu dobiti pomoć [11].

\section{Primarna prevencija}

Primarna prevencija provodi se s ciljem smanjivanja incidencije bolesti. Unatoč nastojanjima da se edukacijskim programima smanji prevalencija korištenja dijeta, namjernog povraćanja i korištenja laksativa među školskom djecom, studije učinkovitosti ovih programa primijenjenih na školsku djecu nisu zadovoljavajuće [15]. Strategija primarne prevencije kao ciljnu skupinu može odabrati onu koja je rizična za razvoj poremećaja jedenja. Međutim, kada bi se u tome uspjelo, ipak ne bi bilo značajnijeg učinka jer pripadnici rizičnih skupina u općoj populaciji bolesnika čine vrlo mali dio. Pokušaj utjecaja na industrije koje se bave modom i dijetama također nije relevantan zbog uloženog kapitala i zarade od promocije mode, hrane ili gubitka na težini [15].

\section{Sekundarna prevencija}

Sekundarna prevencija temelji se na ranom otkrivanju poremećaja kako se ne bi u potpunosti razvili, primjerice u kronična oštećenja [7]. Sekundarna je prevencija važna jer je usmjerena na skraćivanje trajanja bolesti i ubrzavanje intervencija. Potrebno je skratiti interval od nastupa bolesti do traženja pomoći. Treba poznavati faktore koji otežavaju ili olakšavaju traženje pomoći. Prije svega, karakterističan je nedostatak uvida u problem, uvjerenje da će sam od sebe

\section{The role of the nurse in the prevention of eating disorders}

Planning disease prevention and screening programs is a complex process influenced by the views of many participants - both professionals and the general population. Society's attitude towards disease prevention is changing in accordance with worldview, socio-political organization and socio-economic opportunities [14].

Prevention should be implemented from preschool age. The nurse should participate in the development of menus for kindergartens, schools, hospitals and other institutions where children, adolescents and adults spend their time. The goal of health education activities, in addition to exposing children to healthy foods, is to acquaint children with basic concepts related to nutrition, basic nutrients needed for normal body function, recommended daily amounts, but also to get acquainted with basic eating disorders [11].

Prevention of eating disorders can be implemented in schools by organizing workshops for higher grade elementary and high school students with the aim of reducing stereotypes about beauty, body shaping, self-confidence and developing proper eating habits with the aim of more positive attitude and acceptance of one's body [11]. Prevention and screening programs can be applied to the entire population with increased risks of developing the disease or individually to an individual child with or without risk factors [14].

Patients and their families should be referred to self-help associations and groups where they can receive the necessary help and support. By sharing information with other members they will realize that they are not alone. If they feel the disease is spiraling out of control, they can also get information about health facilities where they can get help [11].

\section{Primary prevention}

Primary prevention is carried out with the aim of reducing the incidence of the disease. Despite efforts to reduce the prevalence of diet use, intentional vomiting, and laxative use among school children through educational programs, studies of the effectiveness of these programs applied to school children are unsatisfactory [15]. The primary prevention strategy can select as the target group the one who is at risk for the development of eating disorders, but if it succeeds, there would be no greater effect because members of the risk groups in the general patient population make up a very small part. Attempts to influence the fashion and diet industries have also had problematic success due to the capital behind the industries that make money from fashion, food or weight loss promotion [15].

\section{Secondary prevention}

Secondary prevention is based on early detection of disorders so that they do not fully develop, for example into chronic impairments [7]. Secondary prevention is important because it deals with shortening the duration of the disease and speeding up interventions. It is important to shorten the interval from the onset of the disease to seeking help. One needs to know the factors that make it difficult or easier to seek help. First of all, there is the lack of 
proći te zavaravanje da problem nije dovoljno ozbiljan. U pristupu liječenju bitno je boriti se protiv straha od liječenja koji je prisutan jer se povezuje s dobitkom na težini [15].

\section{Tercijarna prevencija}

Kod tercijarne prevencije radi se na smanjenju dugoročnih posljedica poremećaja i uglavnom odgovara terapiji [7]. Tercijarna prevencija usmjerena je na smanjenje pobola i smrtnosti. Trenutno stanje prevencije poremećaja jedenja opterećeno je nedostatkom relevantnih studija o učinkovitosti preventivnih programa [15].

\section{Zaključak}

Često se smatra da osobe oboljele od poremećaja hranjenja žele usmjeriti pažnju na sebe, no zapravo je potrebno razumjeti složenu etiologiju poremećaja prehrane. Osim bioloških predispozicija, velika pozornost usmjerena je na psihološke i sociokulturalne čimbenike [16]. Značaj se pridaje patološkoj zaokupljenosti i nezadovoljstvu tijelom zbog uloge koju, kao rizični čimbenici, imaju na razvoj depresije, anksioznosti i niskog samopoštovanja [16]. Ranim otkrivanjem i praćenjem oboljelih može se prevenirati prelazak bolesti u kronični oblik i nastanak brojnih zdravstvenih problema. Važno je pratiti zdravstveno stanje svakog pacijenta i biti što dosljedniji u pružanju zdravstvene skrbi. Obitelj, prvenstveno roditelji, najvažniji su faktor u boljem razumijevanju djeteta. Svaki roditelj treba znati da poremećaji hranjenja zapravo nemaju veze s hranom, nego je riječ o emocionalnom zdravlju. Potrebno je biti iskren i uvjeriti svoje dijete da doista nije bitan izgled, već osobnost. Bez obzira na dob pacijenta, važno je uspostavljanje povjerljivog odnosa na relaciji medicinske sestre i pacijenta. Takav odnos doprinosi ranom otkrivanju simptoma, pozitivnoj suradnji s pacijentom i članovima obitelji te lakšem provođenju terapije [17].

\section{Literatura}

[1] Costin C. Poremećaji prehrane 100 pitanja i odgovora. Mozaik knjiga, Zagreb, 2010.

[2] Marčinko D. Poremećaji hranjenja od razumijevanja do liječenja. Medicinska naklada, Zagreb, 2013.

[3] Dalle Grave R. Kako pobijediti poremećaje hranjenja. Veble commerce, Zagreb, 2015.

[4] Horvat I. Anoreksija i Bulimija. Drvo znanja, Zagreb, 2006.

[5] https://www.plivazdravlje.hr/zdravlje-online/bmi; Preuzeto 8. 9. 2020.

[6] Ambrosi-Randić N. Razvoj poremećaja hranjenja. Naklada Slap, Jastrebarsko, 2004.

[7] Davidson G. C., Neale M. J. Psihologija abnormalnog doživljavanja i ponašanja. Naklada Slap, Jastrebarsko, 1999.

[8] Moro LJ. i sur. Psihijatrija. Medicinska naklada, Zagreb, 2011.

[9] Begić D. Psihopatologija. Medicinska naklada, Zagreb, 2014.

[10] Vidović V. Sadašnje stanje i budućnost liječenja i prevencije poremećaja jedenja u Hrvatskoj. Medix, Zagreb, 2004.

[11] Grabić J. Zdravstvena njega oboljelih od anoreksije nervoze - prikaz slučaja. Završni rad. Split: Sveučilište u Splitu, Sveučilišni odjel zdravstvenih studija; 2019. Preuzeto 10. 9. 2020. insight into the problem, the belief that it will pass on its own, and the delusion that the problem is not serious enough. In the treatment approach, it is important to combat the fear of treatment that is present because it is associated with weight gain [15].

\section{Tertiary prevention}

Tertiary prevention works to reduce the long-term consequences of the disorder, and is generally appropriate for therapy [7]. Tertiary prevention works to reduce morbidity and mortality. The current state of prevention of eating disorders is burdened by the lack of relevant studies on the effectiveness of prevention programs [15].

\section{Conclusion}

It is often thought that people with an eating disorder want to focus on themselves, but it is actually necessary to understand the complex etiology of an eating disorder. In addition to biological predisposition, much attention is paid to psychological and sociocultural factors [16]. Much attention is paid to pathological preoccupation and dissatisfaction with the body due to the role they play as risk factors in the development of depression, anxiety and low self-esteem [16]. Early detection and monitoring of patients can prevent the transition of the disease to a chronic form and the emergence of numerous health problems. It is important to monitor the health of each patient and be as consistent as possible in providing health care. The family, and primarily the parents, are the most important factor in understanding a child. Every parent should know that eating disorders are not really related to food, but it is about emotional health. One needs to be honest, and the child needs to be convinced that it's not appearance that matters, but personality. Regardless of the age of the patient, it is important to establish a trusting relationship between the nurse and the patient. Such a relationship contributes to the early detection of symptoms, positive cooperation with the patient and family members, and easier implementation of therapy [17].

\section{Nema sukoba interesa}

\section{Authors declare no conflict of interest}

[12] Američka psihijatrijska udruga: Dijagnostički i statistički priručnik za duševne poremećaje, Međunarodna verzija s MKB-10 šiframa (DSMIVTM), Hrvatsko izdanje: Vera Folnegović-Šmale, Naklada Slap, Jastrebarsko, 1996.

[13] Božić D., Macuka I. Uloga osobnih čimbenika u objašnjenju kompulzivnog prejedanja. Hrvatska revija za rehabilitacijska istraživanja. 2017; 1-16.

[14] Bralić I. i sur. Prevencija bolesti u dječjoj dobi. Medicinska naklada, Zagreb, 2014.

[15] Vidović V. Poremećaji hranjenja i jedenja u ranoj dojenačkoj dobi, djetinjstvu i adolescenciji. Medicus, 2009; 185-91.

[16] Halvorsen J., Heyerdahla S. Girls with Anorexia Nervosa and Young Adults: Personality, Self- Esteem and Life Satisfaction. International Journal of Eating Disorders, 2006.

[17] Sambol K., Cikač T. Anoreksija i bulimija nervoza - rano otkrivanje i liječenje u obiteljskoj medicini. Medicus, Varaždin. 2015; 24 (2): 165-71. 